ELANIT AYZIK

Higher Studies of Israel

\title{
THE THEORETICAL APPROACH TO AWARENESS AS AN INTERDISCIPLINARY CATEGORY - A FEW REFLECTIONS
}

Abstract. Ayzik Elanit, The Theoretical Approach to Awareness as an Interdisciplinary Category - A few Reflections [Teoretyczne podejście do świadomości jako kategorii interdyscyplinarnej - kilka refleksji]. Studia Edukacyjne nr 44, 2017, Poznań 2017, pp. 427-436. Adam Mickiewicz University Press. ISSN 1233-6688. DOI: $10.14746 /$ se.2017.44.27

The article presents different definitions from different disciplines for the concept of "Awareness" and the central role of science in shaping the way teachers think and change their perceptions. In a period of the lack of stability, diversity, and heterogeneity in academic, cultural, and socioeconomic terms, teaching and education become a complicated and demanding tasks for the teacher. The teacher who meets the complex educational challenges finds it difficult to adjust to accelerated and endless social, scientific, and technological changes and to change the perception of his role from a source of knowledge to a transfer of knowledge. Most teachers of our time were not trained to be conscious of the influences of globalization on the lives of the students and communities, differences, equality, and globalization that characterize society as a whole and are required of the teachers in society of our time. The author defines the teachers' consciousness as an Interdisciplinary Category. The increase of the teachers' awareness of the processes of thinking and doing, as a result of the internal and external events around them, may help teachers map their abilities, needs, and expectations, understand the factors of their behavior, plan their course for the future, and define for themselves goals commensurate with the requirements. The awareness grants the teachers an opportunity to take responsibility over the knowledge and thus may change the school experience. ${ }^{1}$

Key words: education, awareness, professional-knowledge, teacher, science, technology, present times

${ }^{1}$ A. Leibowitz, Degree of 'Scientific-ness' of Science, Academia Journal, 2008, 18, p. 4-10; A. Hargreaves, D. Fink, Sustainable Leadership, San Francisco 2006, p. 105; J.L. Kincheloe, Critical pedagogy in the twenty-first century: Evolution for survival, [in:] Critical pedagogy: Where are we now? Eds. P. McLaren, J.L. Kincheloe, Bristol 2007, p. 1-60; M.M. Merryfield, Why Aren't Teachers Being Prepared to Teach for Diversity, Equity and Interconnectedness? A Study of Lived Experience in the Making of Multicultural and Global Educators, Teaching and Teacher Education, 2000, 16, p. 429-443. 


\section{Introduction}

The purpose of this article is to review the subject of teacher's awareness and professional knowledge, while emphasizing the characteristics and changes that are taking place in the modern world and their impact on teaching. Research studies show that teachers are aware ${ }^{2}$ of and present different types of professional knowledge they should use during the fulfillment of their professional obligations. ${ }^{3}$ Experience indicates that until now teachers in Israel still teach according to the traditional model. Frequently the teachers convey knowledge and the students are required to assimilate it. ${ }^{4}$ The students of the new generation are required to learn with emphasis on what interests them. The teachers' task is to plan situations and learning spaces adjusted to the child's development. ${ }^{5}$ Therefore, it is important to understand and to learn the teachers' work style in their personal space and to understand the educational approaches that influence their work style. ${ }^{6}$ All factors in the teachers 'working style are the outcome, to a greater or lesser extent, of the teachers' awareness. ${ }^{7}$ Awareness in teaching is one of the most important factors of professionalism, regardless of the model of education, ${ }^{8}$ which connects to the processing of information through an internal system of visualization in a specific educational environment.

\section{Interdisciplinary approach awareness}

In the accessible literature, there are many different definitions proposed by researchers that represent different disciplines and there is no one agreed-upon theory regarding the concept of 'Awareness', because of the gap between the objective scientific aspect. ' 'Awareness' In modern Western phi-

2 J.L. Kincheloe, Critical pedagogy in the twenty-first century, p. 1-60; K. Illeris, The Fundamentals of Workplace Learning, Understanding How People Learn in Working Life, New York, 2011, p. 46.

${ }^{3}$ E. Hoyle, Professionality, Professionalism and Control in Teaching, [in:] Management in Education: The Management of Organizations and Individuals, Eds. V. Houghton et al., London 1975, p. 318 .

${ }^{4}$ M. Vidislavsky, B. Peled, A. Pavesner, Innovative Pedagogy or Quality Pedagogy in an Innovative Environment, The Four M Pillars, 2011, 27, p. 1-16.

${ }^{5}$ M. Shenar, The Teacher, the Pupil and the School in Reality of Global Cultural, Imagination and Action, 2010, 13, p. 17-44, 31.

${ }^{6} \mathrm{~K}$. Illeris, The Fundamentals of Workplace Learning, p. 46.

${ }^{7}$ K. Illeris, Three Dimensions of Learning: Contemporary Learning Theory in the Tension Field between the Cognitive, the Emotional and the Social, Florida 2003, p. 227.

${ }^{8} \mathrm{~K}$. Illeris, The Fundamentals of Workplace Learning, p. 46.

${ }^{9}$ D.J. Chalmers, Facing up to the Problem of Consciousness, Journal of Consciousness Studies, 1995, 2(3), p. 200-219. 
losophy, is defined in the experiential aspect described through the concept of 'qualia', experience as an input of our senses and feelings. Its shortcoming is that it is limited in thinking. ${ }^{10}$ Modern psychologists define 'awareness' as a cognitive component that enables the absorption of stimuli from the environment and internal stimuli, such as thoughts, emotions, and physical feelings. ${ }^{11}$ Psychological 'awareness' is the highest level of human functioning and understood as the level of mental development to accept the other as a subject of an object. The processes of conscious and controlled information processing necessitate great resources of attention. ${ }^{12}$ In modern sociology, consciousness is a viewpoint that represents public attention to a topic, problem, or social, scientific, or political event and limited by the senses and the memory. ${ }^{13}$ Current pedagogy defines the awareness as the ability to pay attention to personal behavior is what determines the results, ${ }^{14}$ subjective situation of every person as a person, including the teacher, in which the learner structures meaning for knowledge, skills, emotions, and social interaction and develops broader understanding and ability to cope with the practical life challenges. ${ }^{15}$ The homeroom teachers need to aspire to a clear and communicational determination of roles in the school environment. The consciousness is expressed in action, in all that pertains to people and events. ${ }^{16}$ This is an important process that helps a person undergo a change and develop. ${ }^{17}$ The following figure presents the analysis of the different interpretations and the broad spectrum of the concept of 'awareness'.

On the basis of the collected literature, a self-definition of the teacher's consciousness has been developed. Illeris ${ }^{18}$ used the concept and found that consciousness is a subjective process occurring in the teacher, which influences the way he acts and assimilates information in the workplace, which expresses itself not only in the didactic process but also in the engagement A teacher in the acquisition of knowledge, skills, emotions, social interaction developing the ability to see and perform educational tasks with tangible effects. They are extremely important because of the changes in the modern world.

${ }^{10}$ F.J. Varela, Neurophenomenology: A Methodological Remedy for the Hard Problem, Journal of Consciousness Studies, 1996, 3(4), p. 330-349.

${ }^{11}$ J. Bargh, A.E. Kazdin, Encyclopedia of Psychology, Washington DC, New York 2000, 1, p. 347-348.

${ }^{12}$ M.M. Sohlberg, Assessing and Managing Unawareness of Self, Seminars in Speech and Language, 2000, 21(2), p. 135-151.

${ }^{13}$ N. Sillamy, Stownik psychologii, Katowice 1994, p. 54-55.

${ }^{14}$ W. Okoń (Ed.), Pedagogical Dictionary, Warszawa 1992.

${ }^{15}$ D.J. Clandinin, Personal Practical Knowledge: A Study of Teachers' Classroom Images, Journal of Curriculum Inquiry, 2014, p. 361-385.

${ }^{16} \mathrm{~K}$. Illeris, Three Dimensions of Learning, p. 46.

${ }^{17}$ J.A. Johnson, Ascertaining the Validity of Individual Protocols from Web-Based Personality Inventories, Journal of Research in Personality, 2005, 39, p. 103-129.

${ }^{18} \mathrm{~K}$. Illeris, Three Dimensions of Learning. 


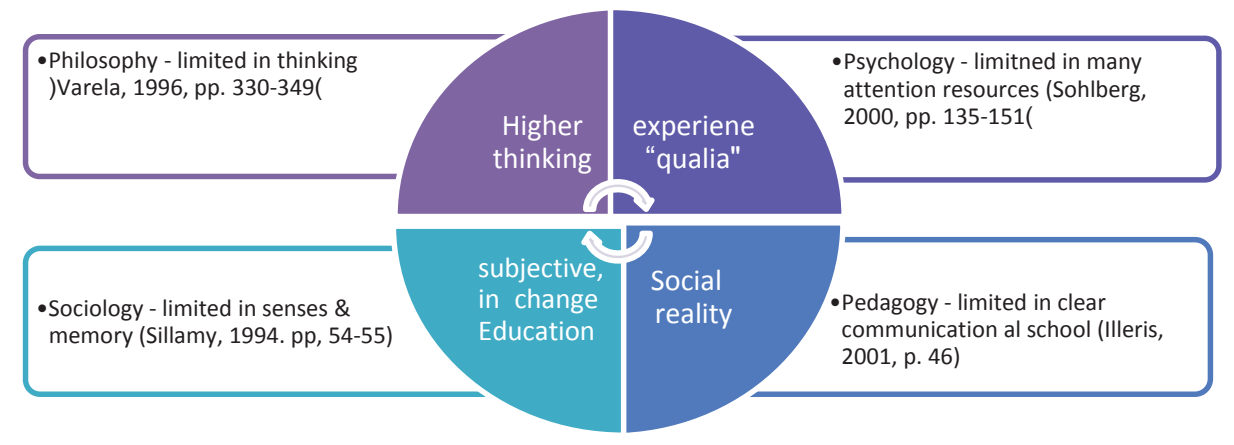

Fig. 1. Conceptual Map of Analysis of Different Interpretations and the Spectrum of 'Awareness'

Source: F.J. Varela, Neurophenomenology: A Methodological Remedy for the Hard Problem, Journal of Consciousness Studies, 1996, 3(4), p. 330-349; James W., The Principles of Psychology (2 volumes in 1), Dover Publications, New York 1950, p. 143-183; N. Sillamy, Stownik psychologii, Katowice 1994, p. 54-55; K. Illeris, The Fundamentals of Workplace Learning, Understanding How People Learn in Working Life, New York, 2011, p. 46

\section{Importance of science for teachers and changes in today's world}

Aside from the purposeful value of science, as serving a defined goal, science has a main role in the shaping of human thinking. Science describes and explains reality, and therefore it influences the manner of thinking and leads to change of perceptions of people and systems. The principles of science in the different areas are adopted by the educational system and become the rules that define its perception. ${ }^{19}$ In a period of the lack of stability, diversity, and heterogeneity in academic, cultural, and socioeconomic terms, teaching and education become a complicated and demanding tasks for the teacher. ${ }^{20}$ Researchers found that there is a difficulty among teachers to implement in actuality scientific theories they learned about learning in teaching and to adjust to rapid changes imposed from above because of the lack of awareness of the chances and their lack of partnership in the determination of the objectives. ${ }^{21}$ The teacher who meets the complex educational challenges finds it difficult to adjust to accelerated and endless social, scientific, and technological changes and to change the perception of his role from a source of knowledge

\footnotetext{
${ }^{19}$ A. Leivovitz, Degree of 'Scientific-ness' of Science, Academia Journal, 2008, 18, p. 4-10.

${ }^{20}$ A. Hargreaves, D. Fink, Sustainable Leadership, San Francisco 2006, p. 105.

${ }^{21}$ M. Peretz, Position Paper on the Topic of the Teacher's Status: New Directions 2009, p. 1-22.
} 
to a transfer of knowledge. ${ }^{22}$ The extension of the phenomenon of difference and globalization of the economy, politics, technology, and environmental systems in the world changed the knowledge and abilities required of young people to be effective citizens in society. Most teachers of our time were not trained to cope with these phenomena and were not trained to be conscious of the influences of globalization on the lives of the students and communities. The training courses of the teachers do not develop knowledge, life experiences with diverse cultures, and awareness of the difference, equality, and globalization that characterize society as a whole and are required of the teachers in society of our time. ${ }^{23}$ In the existing models of teacher training there is a regular gap between the experience and the theoretical learning that indicates the importance of the construction of more integrative training programs. ${ }^{24}$ However, the borders between all the sciences of the social sciences, the behavioral sciences, and the education sciences are rigid, and therefore they are called multidisciplinary. It is also possible that overlap will be created among them. Education aspires to be an applied multidisciplinary area of knowledge, and therefore it cannot disconnect from facts. Since knowledge is multidisciplinary and draws from different areas of knowledge, in the setting of positions in education there are considerations from different areas. ${ }^{25}$ On this background, the importance of the view of the 'big picture' is prominent ${ }^{26}$ in the development of broad pedagogical awareness in the planning of the teachers' teaching.

In this changing reality, new human needs, required for the young generation, the employment of multiple roles during the professional life, and the importance of the acquisition of suitable learning skills arise. Seeing them more aware by:

1. Communication, cooperation, and language; ${ }^{27}$

2. Handling information; ${ }^{28}$

3. High order thinking and self-learning;,29

${ }^{22}$ J.L. Kincheloe, Critical pedagogy in the twenty-first century, p. 1-60.

${ }^{23}$ M.M. Merryfield, Why Aren't Teachers Being Prepared to Teach, p. 429-443.

${ }^{24}$ A. Margolin, Beyond the River - Multiple-Program Path of Training: Training of Teachers as Conversation, Tel Aviv 2010, p. 644-662.

${ }^{25}$ R. Pasternak, Chapters in the Sociology of Education, Tel Aviv 2002.

${ }^{26}$ D. Hanin, Globalization and Its Disappointments: Education in Globalization, Echo of Education, December 2007, p. 36-39.

${ }^{27}$ L. Vygotsky, Learning in a Social Context: Development of Higher Psychological Processes, [in:] Learning in the Social Context, Eds. M. Tsellermeir, A. Kozulin, Tel Aviv 2004, p. 126.

${ }^{28}$ A. Martin, D. Madigan (Eds.), Digital Literacies for Learning, London 2006; A.G. McGrew, P.G. Lewis, Global Politics: Globalization and the Nation State, Cambridge 1992, p. 80.

${ }^{29}$ Y. Harpaz, Give Children Fish: Thinking about Thinking, Echo of Education, April 2009, 73,5, p. 38-44. 
4. Computerized communication instruments, ethics and protection online, ${ }^{30}$

5. Personal development; ${ }^{31}$

Skills for life and career; ${ }^{32}$

For the purpose of the adjustment of the teaching to the learners' needs, It is necessary to develop new ways of learning focus more and more on the learner and on the active learning processes, the flexible structure of the studies, contents adjusted to the social-cultural, economic, and cultural processes of change that invite engagement in actual issues and dilemmas that develop environmental-social consciousness, all this with the integration of technology in the processes of teaching-learning-assessment. ${ }^{33}$ To prepare for innovative learning, it is necessary to develop the ability of self-direction, cooperation, and awareness. ${ }^{34}$

The implications of globalization on education are expressed in the 'economization' of the thinking and the educational action. Education is perceived as an economic resource intended for the improvement of competitiveness in the global economy. The success in the international achievement tests (PISA, TIMSS, etc.) becomes the main goal of the educational system; emphasis on the economy-oriented 'core' studies alongside the reinforcement of the national contents at the expense of the humanistic and artistic contents. ${ }^{35}$ The point is to educate young people so that they can manage themselves and in school and life. To this need is the teacher's awareness and education. ${ }^{36}$ In addition, globalization brings with it contradictions, such as computer technology and information explosion as opposed to the teacher as a source of knowledge, local curricula as opposed to an international and multicultural reality. ${ }^{37}$ The modern changes alter from the foundation the learning conditions and personal space of the teachers and naturally influence the teachers' consciousness. In a global reality that obligates the creation of knowledge in a collaborative manner, teacher is required to be an active member in the professional knowledge community in his professional lifestyle, to open his work to peer feedback and processes of instruction, and to be assisted by the global and

\footnotetext{
${ }^{30}$ A. Martin, D. Madigan (Eds.), Digital Literacies, p. 49.

${ }^{31}$ M. Shenar, The Teacher, the Pupil, p. 31.

${ }^{32}$ J. Salpeter J., 21st Century Skills: Will Our Students Be Prepared? Technology and Learning, 2003, 24(3), p. 17-26.

${ }^{33}$ M. Vidislavsky, B. Peled, A. Pavesner, Innovative Pedagogy, p. 1-16.

${ }^{34}$ S. Merriam, L. Baumgartner, R. Caffarella, Learning in Adulthood: A Comprehensive Guide, San Francisco 2007, p. 275-279.

${ }^{35}$ D. Hanin, Globalization and Its Disappointments, p. 36-39.

${ }^{36}$ N. Aloni, Humanistic Education: Theory into Practice, Education and its Environs: Annual Journal of the HaKibbutz College of Education, 2004, 26, p. 41-49.

${ }^{37}$ G. Resnick, To Build Global Citizenship: Education for Globalization, Echo of Education, December 2007, p. 44-47.
} 
current professional knowledge resources. ${ }^{38}$ The access to social knowledge creates a multicultural discourse between people and different groups, a fact that emphasizes the need for the teachers' awareness of difference and cultural context. ${ }^{39}$ Awareness of issues such as explicit identity and implicit identity, active presence and passive presence, awareness of the learning space, awareness of time and lesson structure, online work routine, and ability to manage time $\mathrm{e}^{40}$ - this awareness will help the teachers understand their role and change the traditional classic A paradigms that hold them captive so as to make a change and fit in.

\section{The Teachers' Consciousness as a Basis for Professional Performance}

Many researchers agree about the importance of consciousness in the processes of thinking in general and its role in the practice of teachers and developed different models for the purpose of the improvement of the quality of the teaching. Hoyle ${ }^{41}$ presents a model of extended professionality that represents the difference between the restricted professionality, in contrast, in improved professionality through the development of the teacher's consciousness. ${ }^{42}$ Critical pedagogy addressed the alternatives of education and maintained that the way to social change, class, social, gender, ethnic, nation$\mathrm{al}$, and racial stratification to which children are born lies in the development of consciousness. ${ }^{43}$ Giroux ${ }^{44}$ presents a model in which the teacher consciously builds knowledge, in this traditional space called the class the teachers have critical responsibility to be conscious that the pedagogy is related necessarily also to the economics, social, and political fields. ${ }^{45}$ Kincheloe $^{46}$ presents a model of post-positive training that shows that teachers build in actuality their practice according to critical knowledge and personal and social con-

${ }_{38}$ T.J. Sergiovanni, Organization, Market and Community vs. Strategies for Changes: What Works Best for Deep Changes in Schools, [in:] International Handbook for Educational Change, Eds. A. Hargreaves et al., Great Britan 1998, p. 576-595.

${ }^{39}$ M. Shenar, The Teacher, the Pupil, p. 17-44.

${ }^{40}$ Ibidem, p. 17-44; A. Shor, P. Freire, What is the Dialogic Teaching Method, [in:] Pedagogy of Release: Dialogues of Change in Education, Tel Aviv 1990, p. 105-126.

${ }^{41}$ E. Hoyle, Professionality, Professionalism, p. 318.

${ }^{42}$ E. Hoyle, Teaching: Prestige, Status and Esteem, Educational Management and Administration, 2001, 29(2), p. 146.

${ }^{43}$ A. Shor, P. Freire, What is the Dialogic, p. 105-126.

${ }^{44}$ H.A. Giroux, Theory and Resistance in Education, Mass 1983, p. 147-151.

${ }^{45}$ H.A. Giroux, Introduction: Democracy, Education, and the Politics of Critical Pedagogy, [in:] Critical Pedagogy: Where Are We Now?, Eds. P. McLaren, J.L. Kincheloe, New York 2007, p. 1-5.

${ }^{46}$ J.L. Kincheloe, Critical pedagogy in the twenty-first century, p. 1-60. 
sciousness. According to the model of learning of Illeris, ${ }^{47}$ the importance of consciousness among teachers is expressed during their action in the school environment as a result of an internal psychological process in which they structure meaning into knowledge, skill, emotions, and social interaction simultaneously and develop a broad understanding and ability to cope with the practical challenges of life. This process includes elements of reflection, transformative and meta-cognitive learning through two processes: (1) personal - perception, memory, and thinking and (2) social - interaction between people. The starting point of Illeris is that the teachers' awareness undergoes a process of change through what the teacher chooses to give attention. Thus, the focus on internal situations is an important component that helps the person undergo a change and develop into a person who cares for and cultivates the 'self', the other, and the environment. teachers hold an interaction with an environment that includes other people, a certain culture, technology in a global and rapidly changing world that proposes many possibilities for learning without limitation ${ }^{48}$ and in the modernity of the present era we are aware of the high frequency of the process of interaction and the power of social influence. ${ }^{49}$

The author broadens the concept of "consciousness" and defines the concept of "teachers' consciousness" as follows. Teachers' consciousness is an interdisciplinary concept of the teacher, which characterizes the challenges of the modern world with emphasis on the development of science and technology that influence the teacher. This is an acquired learning tool that enables cognitive ability to extract a raw reality from the interpretation of attitudes and beliefs and the ability to act effectively in the school. The process of the development of the consciousness through the three stages of FSS:

1. Focusing- "I know what I am doing".

2. Subject interpretation into an objective reality -“I understand why I am doing".

3. Self-Controlling- "I am responsible for my knowledge".

The author defines the teachers' consciousness as an increase in the teacher's ability to think, consider, understand, and solve problems that entails the development of high order thinking skills, techniques and mental abilities through the use of reflection and meta-cognition for the purpose of self-control..$^{50}$ In essence, the desired teacher is the person who knows to address her

${ }^{47}$ K. Illeris, The Fundamentals of Workplace Learning, Understanding How People Learn in Working Life, New York 2011, p. 46.

${ }^{48}$ K. Illeris, Three Dimensions of Learning, p. 227.

${ }^{49}$ K.J. Gergen, Realities and Relationships: Soundings in Social Constructionism, Cambridge 1994, p. 93-143.

${ }^{50}$ Ibidem. 
knowledge. A conscious teacher is a teacher who has experienced a process of the assumption of responsibility and self-control subject also to the influences of the environment. The increase of the teachers' awareness of the processes of thinking and doing, as a result of the internal and external events around them, may help teachers map their abilities, needs, and expectations, understand the factors of their behavior, plan their course for the future, and define for themselves goals commensurate with the requirements. The awareness grants the teachers an opportunity to take responsibility over the knowledge and thus may change the school experience. The article and the defined teacher awareness, is influenced by the Illeris theory that the author has developed.

\section{BIBLIOGRAPHY}

Aloni N., Humanistic Education: Theory into Practice, Education and its Environs: Annual Journal of the HaKibbutz College of Education, 2004, 26.

Bargh J., Kazdin A.E., Encyclopedia of Psychology, Washington DC, US: American Psychological Association, Oxford University Press, New York 2000, 1.

Bauman Z., Globalization: The Humane Aspect (Translated by G. Hazanov), Kav Adom, HaKibbutz HaMeuchad Press, Tel Aviv 2002.

Chalmers D.J., Facing up to the Problem of Consciousness, Journal of Consciousness Studies, 1995, 2(3).

Clandinin D.J., Personal Practical Knowledge: A Study of Teachers' Classroom Images, Journal of Curriculum Inquiry, 2014.

Gergen K.J., Realities and Relationships: Soundings in Social Constructionism, Harvard University Press, Cambridge 1994.

Giroux H.A., Introduction: Democracy, Education, and the Politics of Critical Pedagogy, [in:] Critical Pedagogy: Where Are We Now?, Eds. P. McLaren, J.L. Kincheloe, New York 2007.

Giroux H.A., Theory and Resistance in Education, South Hadley, Mass 1983.

Hanin D., Globalization and Its Disappointments: Education in Globalization, Echo of Education, December 2007.

Hargreaves A., Fink D., Sustainable Leadership, Jossey-Bass, San Francisco 2006.

Harpaz Y., Give Children Fish: Thinking about Thinking, Echo of Education, April 2009, 73, 5.

Hoyle E., Professionality, Professionalism and Control in Teaching, [in:] Management in Education: The Management of Organizations and Individuals, Eds. V. Houghton et al., Ward Lock Educational in Association with Open University Press, London 1975.

Hoyle E., Teaching: Prestige, Status and Esteem, Educational Management and Administration, 2001, 29(2).

Illeris K., Three Dimensions of Learning: Contemporary Learning Theory in the Tension Field between the Cognitive, the Emotional and the Social, Krieger, Malabar, Florida 2003.

Illeris K., The Fundamentals of Workplace Learning, Understanding How People Learn in Working Life, Routledge, New York 2011.

Illeris K., Transformativ learning E identitet, Samfundslitteratur, Copenhagen 2014.

James W., The Principles of Psychology (2 volumes in 1), Dover Publications, New York 1950, s.143-183.

Johnson J.A., Ascertaining the Validity of Individual Protocols from Web-Based Personality Inventories, Journal of Research in Personality, 2005, 39. 
Kincheloe J.L., Critical pedagogy in the twenty-first century: Evolution for survival, [in:] Critical pedagogy: Where are we now? Eds. P. McLaren, J.L. Kincheloe, Open University Press, Bristol 2007.

Leivovitz A., Degree of 'Scientific-ness' of Science, Academia Journal, 2008, 18.

Margolin A., Beyond the River - Multiple-Program Path of Training: Training of Teachers as Conversation, Mofet Institute and Levinsky College of Education, Tel Aviv 2010.

Martin A., Madigan D. (Eds.), Digital Literacies for Learning, Facet Publishing, London 2006.

McGrew A.G., Lewis P.G., Global Politics: Globalization and the Nation State, Polity Press, Cambridge 1992.

Merriam S., Baumgartner L., Caffarella R., Learning in Adulthood: A Comprehensive Guide, Jossey-Bass, San Francisco 2007.

Merryfield M.M., Why Aren't Teachers Being Prepared to Teach for Diversity, Equity and Interconnectedness? A Study of Lived Experience in the Making of Multicultural and Global Educators, Teaching and Teacher Education, 2000, 16.

Okoń W. (Ed.), Pedagogical Dictionary, PWN, Warszawa 1992.

Pasternak R., Chapters in the Sociology of Education, Ramot, Tel Aviv 2002.

Peretz M., Position Paper on the Topic of the Teacher's Status: New Directions 2009.

Resnick G., To Build Global Citizenship: Education for Globalization, Echo of Education, December 2007.

Salpeter J., 21st Century Skills: Will Our Students Be Prepared? Technology and Learning, 2003, 24(3).

Sergiovanni T.J., Organization, Market and Community vs. Strategies for Changes: What Works Best for Deep Changes in Schools, [in:] International Handbook for Educational Change, Eds. A. Hargreaves et al., Kluwer Academic Publishers, Great Britan 1998.

Shenar M., The Teacher, the Pupil and the School in Reality of Global Cultural, Imagination and Action, 2010, 13.

Shor A., Freire P., What is the Dialogic Teaching Method, [in:] Pedagogy of Release: Dialogues of Change in Education, Mifras, Tel Aviv 1990.

Sillamy N., Słownik psychologii, Książnica, Katowice 1994.

Sohlberg M.M., Assessing and Managing Unawareness of Self, Seminars in Speech and Language, 2000, 21(2).

Varela F.J., Neurophenomenology: A Methodological Remedy for the Hard Problem, Journal of Consciousness Studies, 1996, 3(4).

Vidislavsky M., Peled B., Pavesner A., Innovative Pedagogy or Quality Pedagogy in an Innovative Environment, The Four M Pillars, 2011, 27.

Vygotsky L., Learning in a Social Context: Development of Higher Psychological Processes, [in:] Learning in the Social Context, Eds. M. Tsellermeir, A. Kozulin, Tel Aviv 2004. 